Case Report

\title{
IDIOPATHIC GIANT CELL M YOCARDITIS PRESENTING AS SUDDEN CARDIAC DEATH- A RARE CASE REPORT
}

\author{
Harish S. Permi \\ Associate Professor, Department of Pathology, K.S. Hegde M edical Academy, Nitte University \\ Deralakatte, M angalore - 575 018. Karnataka, India. \\ Correspondence \\ Harish S. Permi \\ Associate Professor, Department of Pathology, K. S. Hegde M edical Academy, Nitte University \\ Deralakatte, Mangalore - 575 018, Karnataka, India. \\ Mobile : +919964131827 E-mail : drharish01@ gmail.com
}

\begin{abstract}
:
Idiopathic giant cell myocarditis is a disease of relatively young, predominantly healthy adults which is usually known to cause death in more than half of the cases of sudden death due to heart failure and ventricular arrhythmia. The typical histological features are myocardial necrosis and a rich cellular infiltration of lymphocytes, macrophages, eosinophils, plasma cells and multinucleated giant cells. We report a rare case of idiopathic giant cell myocarditis in a 32 year old healthy male who died suddenly and stress the need to consider as one of the cause of unexplained death in young adults on autopsy.
\end{abstract}

Keywords: Sudden cardiac death, Idiopathic giant cell myocarditis.

\section{Introduction :}

Idiopathic giant cell myocarditis (IGCM) is a rare clinicopathological entity which is usually known to cause in more than half the cases sudden death. The histological features are characteristic with a central area of myocardial necrosis and a rich cellular infiltration of lymphocytes with a few eosinophils, plasma cells, macrophages and multinucleated giant cells. ${ }^{[1]}$ It is a disease of relatively young, predominantly healthy adults. The patients usually die of heart failure and ventricular arrhythmia. ${ }^{[2]}$ We report a rare case of idiopathic giant cell myocarditis in a 32 year old healthy male who died suddenly. Our case report stress the need to consider IGCM as one the cause for unexplained sudden death in young adults on autopsy.

\section{Case Report :}

A 32-year old male died suddenly. As per the family

Access this article online Quick Response Code

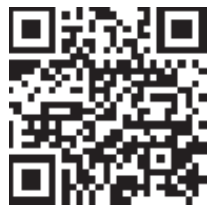
members there was no history of any medical illness and he was healthy. An autopsy was performed at the Government medical college, to know the cause of sudden death. External examination did not show any obvious abnormality. Heart and other internal organs were sent for histopathological examination. Weight of heart was $300 \mathrm{gm}$. Coronary arteries were patent and the ventricular wall thickness was normal. On gross examination, there were greywhite lesions on the anterior surface of the right and left ventricle. Microscopy from these lesions showed myocyte necrosis, dense infiltration with lymphocytes, plasma cells, eosinophils and multinucleated giant cells. [Figure 1,2] Special stained sections for acid fast bacilli and fungi were negative. Giant cells lacked asteroid and Schaumann bodies. All the other organs were unremarkable. Final diagnosis of idiopathic giant cell myocarditis was suggested and considered as the cause of death.

\section{Discussion :}

Myocarditis is a group of pathologic entities in which infectious micro-organisms and/or inflammatory processes cause myocardial injury. A rare type of this disease is idiopathic giant cell myocarditis. ${ }^{[3]}$ Sudden cardiac death is defined as an unexpected death which results from cardiac causes in individuals without heart disease or with an early after symptom onset, usually within 1 hour. IGCM is usually known to cause death in more than half of the cases of sudden death. ${ }^{[1]}$ Major 


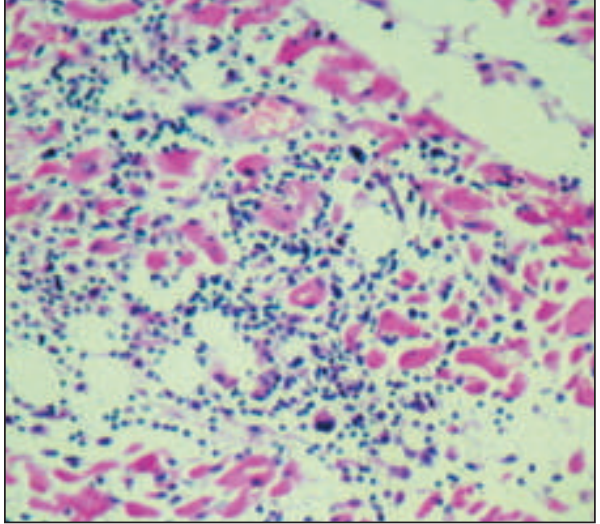

Figure 1) Microscopy showing cardiac myocytolysis, infiltration with lymphocytes, plasma cells and multinucleated giant cells. (Hematoxylin \& Eosin X100)

symptom is rapid progressive heart failure or con-comitant ventricular arrhythmias. Its high morbidity and mortality are due to its refractory response to all forms of treatment. ${ }^{[4]}$ Etiology of Giant Cell M yocarditis is associated with autoimmune disease like inflammatory bowel disease. Few cases of giant cell myocarditis showed an association with hypersensitivity reactions, lymphomas, thymomas and myasthenia gravis. ${ }^{[5]}$ The disorders showing myocardial granulomas with associated giant cells, which can be mistaken for idiopathic giant cell myocarditis are rheumatic myocarditis, tuberculosis, cryptococcosis, sarcoidosis and syphilitic myocarditis. ${ }^{[2]}$ The typical histological picture in cases of IGCM is widespread circumscribed area of myocardial necrosis and a rich cellular infiltration of lymphocytes with a few macrophages, eosinophils, plasma cells and multinucleated giant cells with necrotic areas. ${ }^{[3]}$ Tuberculosis and cryptococcosis also have giant cells within

\section{References:}

1. Konapur PG, Dhaded AV, Udayakumar M. Idiopathic giant cell myocarditis-a rare case report and review of literature. Indian J Pathol Microbiol 2003; 46:241-3.

2. Kalpana Kumari M .K, Vijaya. V. M ysorekar, Praveen S. Idiopathic giant cell myocarditis-A rare case report.J Clin Diagn Res 2012; 6: 1425-7.

3. Momin YA, Raghuvanshi SR, Lanjewar DN. Idiopathic giant cell myocarditis leading to sudden death - A case report. Bombay Hosp J. 2008: 50:288-9.

4. Blauwet LA, Cooper LT. M yocarditis. Prog CardioVasc Dis 2010; 52:27488

5. Laufs H, Nigrovic PA, Schneider LC, Oettgen H, Del NP, M oskowitz IP. Giant cell myocarditis in a 12-year-old girl with a common variable immunodeficiency. Mayo Clin Proc 2002; 77:92-6.

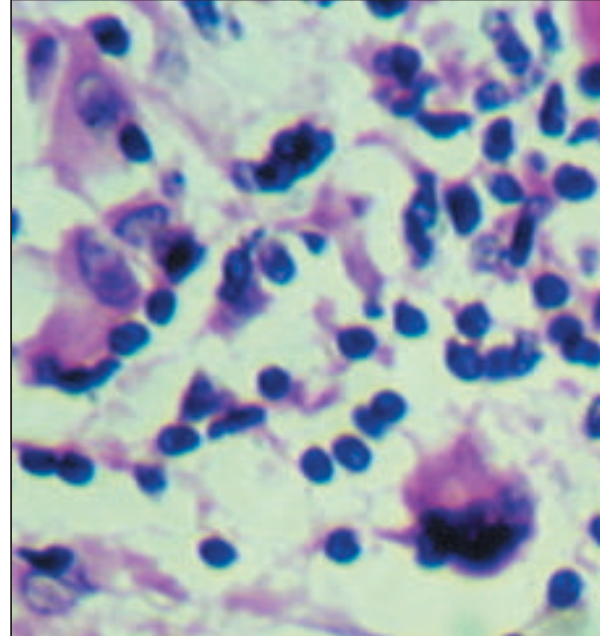

Figure 2) Microscopy showing multinucleated giant cells and lymphocytes. (Hematoxylin \& Eosin X 400)

the granulomatous lesions. Special stains for the organisms should be performed in tuberculosis and cryptococcosis. Rheumatic myocarditis show characteristic interstitial granulomas with giant cells. Syphilitic myocarditis and systemic sarcoidosis usually have distinct clinical presentations and the appropriate diagnostic studies can usually prevent their confusion with idiopathic giant cell myocarditis.

\section{Conclusion :}

Idiopathic giant cell myocarditis is a disease of relatively young predominantly healthy adults which presents as sudden cardiac death as seen in our case. We stress to consider IGCM as one of the cause of unexplained sudden death in young healthy adults on autopsy. 